\title{
PENGARUH MODAL SOSIAL TERHADAP PERMINTAAN PANGAN RUMAHTANGGA TANI DI PROVINSI RIAU
}

\author{
THE SOCIAL CAPITAL EFFECT ON FOOD DEMAND BY THE FARMER HOUSEHOLDS IN \\ RIAU PROVINCE
}

\author{
Fahmi W. Kifli*1, Jangkung H. Mulyo ${ }^{* * * * * *}$, Dwidjono Hadi Darwanto**), dan Slamet Hartono ${ }^{* *)}$ \\ *) Departemen Agribisnis, Fakultas Pertanian, Institut Pertanian "STIPER” Yogyakarta \\ Jl. Nangka II, Maguwoharjo (Ringroad Utara), Yogyakarta 55281 \\ **) Departemen Sosial Ekonomi Pertanian, Fakultas Pertanian, Universitas Gadjah Mada Yogyakarta \\ JL. Flora Bulaksumur, Yogyakarta 55281 \\ ${ }^{* * *}$ Pusat Studi Kebijakan dan Kependudukan, Universitas Gadjah Mada Yogyakarta \\ Jl. Tevesia, Sleman, Yogyakarta 55281
}

\begin{abstract}
The objectives of this study were to analyze the factors that affected the food demand by the farmer households in Riau Province and to analyze how social capital is influential toward this demand. The research was conducted in four districts with different characteristics including Indragiri Hilir and Rokan Hilir as the regional representation with high activities of food crops, while Kampar and Rokan Hulu as the regional representation to the medium activities of food crops. The study was conducted in the two-survey period. The first survey was carried out in Indragiri Hilir and Kampar Regencies with the number of households as many as 114 in 2013, and the second survey was conducted in Rokan Hilir and Rokan Hulu Regencies with the number of households of 96 farm households in 2014 so that the total samples reached 210 farm households 4. The sampling was carried out randomly. The function of farmer household food demand was analyzed using the model of farm household and was estimated by Ordinary Least Sguare (OLS). The results showed that the variables of age of the household head, education level of farmers, number of household members, household income, and social capital had positive effects on the food demand for the farmer households while the variables of the prices of rice, potatoes, eggs, chicken meat, fish, and cooking oil had negative effects on the food demand for the farmer households in Riau Province. Furthermore, the results showed that social capital in the society built on the four (4) aspects, namely, trust, social networks within the support structure, norms and values, and levels of participation in the organization has contributed positively to food security of the farmers in Riau Province. Therefore, the community needs to build a high social capital, cooperation and mutual assistance, especially for the environment that has difficulties in finding food.
\end{abstract}

Keywords: social capital, demand, food, farm household, food security

\begin{abstract}
Abstrak: Tujuan penelitian ini adalah menganalisis faktor-faktor yang memengaruhi permintaan pangan rumahtangga tani di Provinsi Riau dan bagaimana kaitan modal sosial berbengaruh di dalamnya. Penelitian ini dilakukan pada empat kabupaten dengan karakteristik berbeda yang ada di Provinsi Riau, kabupaten Indragiri Hilir dan Rokan Hilir sebagai representasi daerah dengan aktivitas pertanian yang tinggi, sedangkan Kabupaten Kampar dan Rokan Hulu mewakili daerah dengan aktivitas pertanian sedang. Survei dalam penelitian ini dilakukan dalam dua periode, dimana tahun 2013 pada Kabupaten Kampar dan Indragiri Hilir sebanyak 114 sampel, dan tahun 2014 di Kabupaten Rokan Hulu dan Rokan Hilir sebanyak 96 sampel, sehingga total berjumlah 210 sampel rumahtangga tani. Metode pengambilan sampel dilakukan secara acak. Analisis permintaan pangan rumahtangga tani menggunakan model rumahtangga tani itu sendiri dengan alat analisis Ordinary Least Sguare (OLS). Hasil penelitian menunjukkan bahwa variabel, usia kepala rumahtangga, tingkat pendidikan, jumlah anggota rumahtangga, pendapatan rumahtangga dan modal sosial memberikan pengaruh signifikan terhadap konsumsi dan permintaan pangan rumahtangga, adapun variabel harga-harga seperti harga beras, harga ubi, harga telur, harga daging ayam, harga ikan dan harga minyak goreng menunjukkan koefisien negatif dan tidak berpengaruh signifikan terhadap permintaan pangan rumahtangga tani. Lebih lanjut, modal sosial yang ada di masyarakat yang tersusun 4 (empat) aspek, yakni kepercayaan, jaringan sosial dalam struktur dukungan, norma dan nilai, dan tingkat partisipasi dalam organisasi berkontribusi positif terhadap ketahanan pangan rumahtangga tani. Untuk itu masyarakat perlu membangun modal sosial yang tinggi, kerjasama dan saling membantu, khususnya terhadap lingkungannya yang kesulitan memperoleh pangan.
\end{abstract}

Keywords: modal sosial, permintaan, pangan, rumah tangga tani dan ketahanan pangan

\author{
${ }^{1}$ Corresponding author: \\ Email: odone_marshall@yahoo.com
}




\section{PENDAHULUAN}

Pemerintah pusat maupun pemerintah daerah perlu melaksanakan peran fasilitasi dan intervensi sesuai kewenangan otonominya untuk memfungsikan sistem ketahanan pangan secara optimal dan adil bagi seluruh pelakunya. Penciptaan ketahanan pangan perlu dilakukan sebagai wahana penguatan otonomi daerah dan stabilitas ekonomi dan politik, jaminan ketersediaan pangan dengan harga yang terjangkau dan menjanjikan untuk mendorong peningkatan produksi. Sektor pertanian merupakan sektor yang sangat penting baik dalam jangka pendek maupun dalam jangka panjang pembangunan ekonomi. Oleh karena itu, kebijakan pembangunan pertanian seharusnya diarahkan agar sektor pertanian menjadi sektor yang tangguh dalam jangka pendek maupun jangka panjang (Masyhuri, 2001). Napitupulu (2005) menyatakan bahwa sektor pertanian memiliki peran strategis bagi negara sebagai mata pencaharian sebagian besar penduduk, sebagai bahan baku industri, sumber devisa dan juga sebagai pendapatan Negara. Pengalaman empiris membuktikan bahwa ternyata sektor pertanian yang menjadi juru selamat negeri ini, dimana pada fase 1997-2001 sektor pertanian menjadi satu-satunya sektor yang tetap tumbuh positif kendati melambat sedangkan sektor ekonomi lainnya justru tumbuh negatif (Wiryamarta dan Mulyo, 2009).

Hasbullah (2006) menjelaskan, modal sosial sebagai segala sesuatu hal yang berkaitan dengan kerja sama dalam masyarakat atau bangsa untuk mencapai kapasitas hidup yang lebih baik, ditopang oleh nilainilai dan norma yang menjadi unsur-unsur utamanya seperti rasa saling mempercayai, keimbal-balikan, aturan-aturan kolektif dalam suatu masyarakat atau bangsa dan sejenisnya. Modal sosial menurut Cohen and Prusak (2001), adalah sebagai setiap hubungan yang terjadi dan diikat oleh suatu kepercayaan (trust), kesaling pengertian (mutual understanding), dan nilainilai bersama (shared value) yang mengikat anggota kelompok untuk membuat kemungkinan aksi bersama dapat dilakukan secara efisien dan efektif.

Modal sosial (social capital) dapat didefinisikan sebagai kemampuan masyarakat untuk bekerja bersama, demi mencapai tujuan-tujuan bersama, di dalam berbagai kelompok dan organisasi (Coleman, 1999). Partha dan Ismail (1999) mendefinisikan modal sosial sebagai hubungan-hubungan yang tercipta dan norma-norma yang membentuk kualitas dan kuantitas hubungan sosial dalam masyarakat dalam spektrum yang luas, yaitu sebagai perekat sosial (social glue) yang menjaga kesatuan anggota kelompok secara bersama-sama. Pada jalur yang sama Solow (1999) mendefinisikan modal sosial sebagai serangkaian nilai-nilai atau norma-norma yang diwujudkan dalam perilaku yang dapat mendorong kemampuan dan kapabilitas untuk bekerjasama dan berkoordinasi untuk menghasilkan kontribusi besar terhadap keberlanjutan produktivitas.

Modal sosial yang kuat dalam masyarakat maka diharapkan risiko kelaparan akan semakin kecil. Fukuyama (1995) mendefinisikan modal sosial sebagai serangkaian nilai-nilai atau norma-norma informal yang dimiliki bersama diantara para anggota suatu kelompok yang memungkinkan terjalinnya kerja sama diantara mereka. Adapun Cox (1995) mendefinisikan modal sosial sebagai suatu rangkaian proses hubungan antar manusia yang ditopang oleh jaringan, normanorma, dan kepercayaan sosial yang memungkinkan efisien dan efektifnya koordinasi dan kerjasama untuk keuntungan dan kebaikan bersama. Burt (1992) secara lebih komperehensif mendefinisikan bahwa modal sosial adalah kemampuan masyarakat untuk melakukan asosiasi (berhubungan) satu sama lain dan selanjutnya menjadi kekuatan yang sangat penting bukan hanya bagi kehidupan ekonomi. Akan tetapi, juga setiap aspek eksistensi sosial yang lain.

Modal sosial dalam ini dilihat dari aspek: kepercayaan (trust), norma (norms) dan nilai (values), dan jaringan sosial (networking). Modal sosial yang berkembang di masyarakat dewasa ini diharapkan mampu mendorong penguatan rumah tangga dalam peningkjatan kapasitas produksi dan juga kemampuan akses terhadap pangan. Telah banyak penelitian yang meneliti hubungan antara modal sosial, insolation dan dukungan sosial pada kesehatan. Namun, penelitian tentang kontribusi modal sosial terhadap kemampuan rumah tangga untuk mengakses pangan yang memadai dan upaya meningkatkan ketahanan pangan belum dikaji lebih jauh mengenai.

Pendekatan konsep yang digunakan dalam penelitian ini adalah konsep permintaan terhadap barang yang akan dikonsumsi. Permintaan adalah jumlah barang/ jasa yang diminta oleh konsumen pada berbagai tingkat harga. Permintaan terhadap barang, selain dipengaruhi oleh faktor harga, juga dipengaruhi oleh faktor lain seperti pendapatan, harga barang lain yang berhubungan, selera, dan lain-lain. Keputusan konsumen untuk mengkonsumsi barang bertujuan 
agar memberikan kepuasan tertinggi atas barang yang dikonsumsi tersebut sesuai dengan pendapatan yang dimiliki.

Fungsi permintaan dapat dinyatakan dalam hubungan matematika antara jumlah barang yang diminta dengan faktor-faktor yang memengaruhinya. Melalui fungsi tersebut dapat diketahui hubungan jumlah barang yang diminta dengan variabel yang memengaruhinya. Rumah tangga tani memiliki keunikan tersendiri, hal ini mengingat bahwa pada rumah tangga tani terdapat beragam aktivitas, diantaranya: konsumsi, produksi dan juga suplai tenaga kerja. Semua aktivitas tersebut saling berkaitan dan tidak dapat dipisahkan satu dan lainnya. Rumah tangga tani disamping sebagai produsen pangan sekaligus pula sebagai konsumen, dimana hasil produksi dikonsumsi dan sebagian lain akan dijual sebagai modal usahatani berikutnya. Pada umumnya rumah tangga tani memiliki sifat subsisten, meskipun tidak jarang pula yang bersifat komersial.

Nakajima (2004) menyatakan bahwa pada tingkat upah yang ditentukan oleh pasar tenaga kerja maka rumah tangga tani dapat menjual sebagian tenaga kerja ke luar usahatani, sebaliknya juga dapat membeli sebagian tenaga kerja dari luar untuk kegiatan usahataninya. Alokasi tenaga kerja dan waktu kerja rumah tangga tani untuk aktivitas usahatani dan non usahatani sesungguhnya bertujuan memaksimalkan utilitas rumah tangga. Lebih lanjut, Sadoulet and Janvry (1995) mengemukakan bahwa keputusan untuk melakukan konsumsi, produksi, leisure atau bekerja di dalam rumah tangga dilakukan oleh rumah tangga tani itu sendiri. Selanjutnya, untuk menganalisis aktivitas ekonomi rumah tangga tani hendaklah menggunakan model rumah tangga tani itu sendiri. Replika ekonomi rumah tangga menjelaskan bahwa pendapatan bersifat endogen maka keputusan konsumsi tidak bisa dilepaskan dengan keputusan produksi. Hal ini sejalan dengan model ekonomi neo-klasik, dimana analisis konsumsi tidak dapat dipisahkan dengan keputusan produksi yang bersumber pada tahapan analisis yang terpisah apakah bersifat konsumen murni dan produsen murni. Keputusan anggota rumah tangga untuk bekerja serta penggunaan waktu berhubungan erat dengan siklus kehidupan rumah tangga.

Banyak studi yang menunjukkan hubungan positif antara modal sosial dan tingkat kesehatan (Kawachi et al. 1997; Rose, 2000; Runyan et al. 1998) hubungan modal sosial dan pengurangan angka kriminalitas
(Sampson, Raudenbush \& Earls, 1997; Kawachi et al 1999; Kennedy et al 1998), tetapi tidak banyak yang meneliti hubungan potensial antara modal sosial terhadap permintaan pangan. Selanjutnya, penelitian ini bertujuan untuk mengestimasi pengaruh modal sosial terhadap permintaan pangan rumah tangga petani padi di Provinsi Riau.

Penelitian ini dilakukan dengan mengestimasi variabelvariabel yang berkaitan pada permintaan pangan rumah tangga, dan seberapa besar variabel modal sosial yang ada di masyarakat dapat berpengaruh terhadap permintaan rumah tangga tani. Faktor-faktor yang diduga berpengaruh antara lain: harga beras, harga ubi, harga telur, harga daging ayam, harga ikan, harga minyak goreng, usia kepala rumah tangga, tingkat pendidikan petani, jumlah anggota rumah tangga, pendapatan rumah tangga, dan modal sosial. Berdasarkan hal tersebut, analisis faktor-faktor yang diduga memengaruhi permintaan pangan rumah tangga tani sangat penting untuk dilakukan. Kajian modal sosial difokuskan terhadap bagaimana rumah tangga meningkatkan permintaan pangan dan juga ketahanan pangannya, terutama pada aspek modal sosial masyarakat dari aspek: kepercayaan (trust), jaringan sosial dan struktur dukungan, norma (norms) dan nilai (values), dan tingkat partisipasi dalam organisasi (networking). Modal sosial yang ada di masyarakat diharapkan mampu memperbaiki tingkat permintaan pangan rumah tangga tani di Provinsi Riau.

\section{METODE PENELITIAN}

Pemilihan Provinsi Riau sebagai daerah penelitian berdasarkan pertimbangan bahwa pertumbuhan sektor pertanian di Provinsi Riau yang lebih tinggi dari pertumbuhan sektor pertanian di tingkat Nasional. Nilai PDRB perkapita Provinsi Riau merupakan urutan ke empat terbesar di Indonesia setelah DKI Jakarta, Kalimantan Timur, dan Kepulauan Riau (BPS, 2015).

Penelitian ini menganalisis modal sosial terhadap permintaan pangan di tingkat rumah tangga tani di Provinsi Riau, dengan mengambil empat kabupaten dengan karakteristik yang berbeda sebagai wilayah kajian, yakni Kabupaten Indragiri Hilir dan Kabupaten Rokan Hilir sebagai representasi daerah dengan aktivitas pertanian tanaman pangan yang tinggi. Sedangkan Kabupaten Kampar dan Kabupaten Rokan Hulu sebagai representasi daerah dengan aktivitas pertanian 
tanaman pangan yang sedang. Dari keempat kabupaten tersebut kemudian diambil beberapa kecamatan sebagai wilayah penelitian, dimana kecamatan-kecamatan tersebut merupakan representasi wilayah yang memiliki aktivitas pertanian padi.

Jenis data yang digunakan dalam penelitian ini meliputi data primer dan data sekunder. Data sekunder dikumpulkan dari dinas dan instansi terkait, dan juga didapat melalui beberapa sumber dan publikasi terkait, sedangkan data primer yang dikumpulkan meliputi data aktivitas usahatani selama satu tahun yang meliputi semua aspek kegiatan usahatani yaitu penggunaan input setiap usaha dan setiap musim, sesuai jenis, jumlah/ volume, dan harganya, serta hasil-hasil produksi, harga yang diterima, dan besarnya penerimaan usahatani.

Pengumpulan data aktivitas ekonomi petani di luar usahatani juga dilakukan, meliputi jenis kegiatan, waktu, tempat, dan pendapatan yang diperoleh dari setiap kegiatannya dan juga data karakteristik petani yang harus dicatat meliputi umur, pendidikan formal, jumlah anggota rumah tangga, jumlah anggota rumah tangga yang bekerja, luas pemilikan lahan, dan luas penguasaan lahan menurut jenis lahan yang dikuasai.
Dalam penelitian dilakukan dua periode survei, yakni tahun 2013 dan 2014. Pada tahun 2013 terdapat 2 (dua) kabupaten, yakni Kabupaten Indragiri Hilir dan Kabupaten Kampar sedangkan tahun 2014 dilakukan hal yang sama untuk Kabupaten Rokan Hilir dan Kabupaten Rokan Hulu. Metode dalam penentuan atau pengambilan sampel dilakukan secara acak. Total jumlah sampel yang dianalisis adalah 210 rumah tangga tani yang terdiri dari 114 rumah tangga tani tahun 2013 dan 96 rumah tangga tani tahun 2014. Kerangka pemikiran penelitian selengkapnya pad Gambar 1 .

Fungsi permintaan dapat dinyatakan dalam hubungan matematika antara jumlah barang yang diminta dengan faktor-faktor yang memengaruhinya. Melalui fungsi tersebut dapat diketahui hubungan jumlah barang yang diminta dengan variabel yang memengaruhinya. Secara matematis fungsi permintaan dapat ditulis (Pyndick dan Rubinfeld, 1998b): $Q_{x}=f\left(P_{x}, P_{y}, I\right.$, selera, ......) dengan $\mathrm{Q}_{\mathrm{x}}$ (jumlah barang $\mathrm{x}$ yang dibeli); $\mathrm{P}_{\mathrm{x}}$ (harga barang $\mathrm{x}$ ); $\mathrm{P}_{\mathrm{y}}$ (harga barang $\mathrm{y}$, dimana $\mathrm{y}$ merupakan barang yang mempunyai hubungan dengan barang $\mathrm{x}$ ); I (pendapatan).

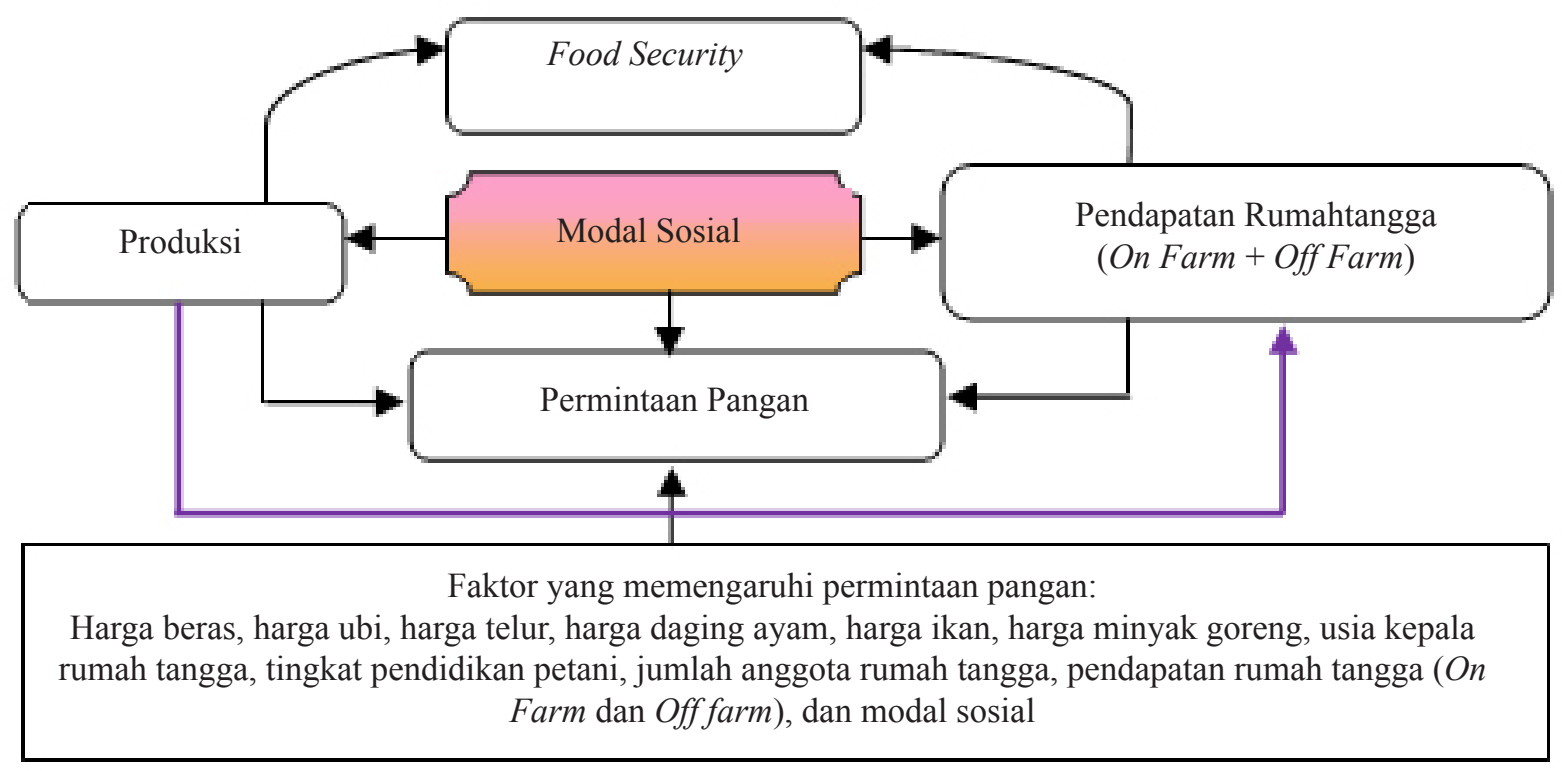

Gambar 1. Kerangka pemikiran penelitian 
Singh et al. (1986) mengembangkan model ekonomi rumah tangga, dan Becker (1965) membangun teori ekonomi rumah tangga secara umum tanpa aplikasi kegiatan rumah tangga secara spesifik. Teori tersebut pada dasarnya merelaksasi Model Marshall yang menganggap pendapatan rumah tangga bersifat endogen (money income held constant). Singh et al. (1986) melihat bahwa anggaran rumah tangga bersifat endogenous, sedangkan di dalam Model Marshall anggaran bersifat eksogenous. Oleh karena itu apa yang dilakukan oleh Singh et al. (1986) dan Becker (1965) pada dasarnya adalah melonggarkan asumsi yang digunakan oleh ahli ekonomi neo-klasik dalam menganalisis perilaku ekonomi rumah tangga. Chalamwong (1985) mengembangkan model rumah tangga tani dengan menambahkan variabel kontrol dari karakteristik rumah tangga seperti umur, tingkat pendidikan dan jumlah anggota rumah tangga ke dalam fungsi utilitas.

Fungsi permintaan (Qd) dirumuskan:

$$
\mathrm{Q}_{\mathrm{d}}=\alpha_{0}+\alpha_{1} \mathrm{P}+\alpha_{2} \mathrm{P}_{0}+\alpha_{3} \mathrm{Y}+\mathrm{U}_{1}
$$

Permintaan akan barang $\left(\mathrm{Q}_{\mathrm{d}}\right)$ tergantung pada harga barang itu sendiri $(\mathrm{P})$, harga barang lain $\left(\mathrm{P}_{0}\right)$ dan pendapatan $(\mathrm{Y})$. Selanjutnya fungsi konsumsi :
$\mathrm{C}_{\mathrm{t}}=\beta_{0}+\beta_{1} \mathrm{Y}_{\mathrm{t}}+\mathrm{U}_{2}$

$\mathrm{Y}_{\mathrm{t}}=\mathrm{C}_{\mathrm{t}}+\mathrm{I}_{\mathrm{t}}$

Keterangan: $\mathrm{C}$ (konsumsi); $\mathrm{Y}$ (pendapatan); I( investasi); $\mathrm{U}$ (residual); dan $\mathrm{t}$ (waktu yang menunjukkan variabel yang diamati dalam waktu tertentu). Selanjutnya dengan mensubstitusikan Y maka diperoleh persamaan berikut :

$\mathrm{C}_{\mathrm{t}}=\beta_{0}+\beta_{1}\left(\mathrm{C}_{\mathrm{t}}+\mathrm{I}_{\mathrm{t}}\right)+\mathrm{U}_{2}$

Secara ekonometrik (Greene, 1993 dan Gudjarati, 2003) dapat dituliskan sebagai berikut :

$\mathrm{LnPP}=\ln \beta_{0}+\beta_{1} \ln \mathrm{H}_{\mathrm{Brs}}+\beta_{2} \ln \mathrm{H}_{\mathrm{Ubi}}+\beta 3 \ln \mathrm{H}_{\mathrm{Tr}}+\beta 4 \ln \mathrm{H}_{\text {Ayam }}$ $+\beta_{5} \ln \mathrm{n}_{\mathrm{Ikan}}+\beta 6 \ln \mathrm{H}_{\mathrm{Mgr}}+\beta 7 \operatorname{lnUKR}+\beta 8 \ln \mathrm{nik}+$ $\beta_{9} \operatorname{lnJART}+\beta_{10} \operatorname{lnI}_{\mathrm{RT}}+\beta_{11} \ln \mathrm{SC}+\varepsilon$

Keterangan: PP (permintaan pangan); $\beta_{0}$ (intercept); $\beta_{1, \ldots, 11}$ (koefisien regresi (parameter yang ditaksir)); $\mathrm{H}_{\text {Brs }}$ (harga beras $(\mathrm{Rp} / \mathrm{Kg})$ ); $\mathrm{H}_{\mathrm{Ubi}}$ (harga ubi $(\mathrm{Rp} / \mathrm{Kg})$ ); $\mathrm{H}_{\mathrm{Tl}}$ (harga telur $(\mathrm{Rp} / \mathrm{Kg})) ; \mathrm{H}_{\text {Ayam }}$ (harga daging ayam $(\mathrm{Rp} /$ $\mathrm{Kg})$ ); $\mathrm{H}_{\text {Ikan }}$ (harga ikan $\left.(\mathrm{Rp} / \mathrm{Kg})\right) ; \mathrm{H}_{\mathrm{Mgr}}$ (harga minyak goreng $(\mathrm{Rp} / \mathrm{Kg})$ ); UKR (usia kepala rumah tangga (tahun)); Dik (tingkat pendidikan petani (tahun)); JART (jumlah anggota rumah tangga (orang)); $\mathrm{I}_{\mathrm{RT}}$ (pendapatan rumah tangga (Rp)); $\mathrm{SC}($ modal sosial); $\varepsilon$ (error term).

Tabel 1. Hasil estimasi modal sosial terhadap permintaan pangan rumah tangga tani di Provinsi Riau

\begin{tabular}{|c|c|c|c|c|}
\hline Variabel & Peubah & Koefisien regresi & Standart error & t-ratio \\
\hline Konstanta & $\beta 0$ & $3,0579 \mathrm{NS}$ & 2,2882 & 0,183 \\
\hline Harga beras & $\beta 1$ & $-0,1677^{*}$ & 0,0961 & $-1,744$ \\
\hline Harga ubi & $\beta 2$ & $-0,0099 \mathrm{NS}$ & 0,0528 & $-0,186$ \\
\hline Harga telur & $\beta 3$ & $-0,0805 * * *$ & 0,0329 & $-2,443$ \\
\hline Harga ayam & $\beta 4$ & $-0,0659 \mathrm{NS}$ & 0,0708 & $-0,931$ \\
\hline Harga ikan & $\beta 5$ & $-0,0096 \mathrm{NS}$ & 0,0351 & $-0,274$ \\
\hline Harga minyak goreng & $\beta 6$ & $-0,2321 * * *$ & 0,0634 & $-3,660$ \\
\hline Usia kepala rumahtangga & $\beta 7$ & $0,2131 *$ & 0,1209 & 1,762 \\
\hline Tingkat pendidikan petani & $\beta 8$ & $0,1459^{* *}$ & 0,0734 & 1,989 \\
\hline Jumlah anggota rumahtangga & $\beta 9$ & $0,4228 * * *$ & 0,0692 & 6,108 \\
\hline Pendapatan rumahtangga & $\beta 10$ & $0,0243 \mathrm{NS}$ & 0,0204 & 1,189 \\
\hline Modal sosial & $\beta 11$ & $1,3043 * * *$ & 0,4886 & 2,670 \\
\hline Koefisien determinasi (R2) & & & 0,6395 & \\
\hline F-hitung & & & & $31,926^{* * *}$ \\
\hline Jumlah sampel (n) & & & 210 & \\
\hline
\end{tabular}

Keterangan: $* * *=$ signifikan pada kesalahan $1 \%$; ** = signifikan pada kesalahan $5 \%$; $*$ signifikan pada kesalahan $10 \%$; $\mathrm{NS}=$ non signifikan pada kesalahan $10 \%$; t-tabel $1 \%=2,358 ; \mathrm{t}$-tabel $5 \%=1,980 ; \mathrm{t}$-tabel $10 \%=1,658 ; \mathrm{F}$-tabel $1 \%=$ 3,920 . 


\section{HASIL}

Modal sosial masyarakat dalam penelitian ini dilihat dari empat aspek, yakni kepercayaan, jaringan sosial dalam struktur dukungan, norma dan nilai, dan tingkat partisipasi dalam organisasi. Namun, secara keseluruhan faktor-faktor yang diduga memengaruhi permintaan pangan rumah tangga petani padi selain modal sosial adalah harga beras, harga ubi, harga telur, harga daging ayam, harga ikan, harga minyak goreng, usia kepala rumah tangga, tingkat pendidikan petani, jumlah anggota rumah tangga, dan pendapatan rumah tangga. Analisis fungsi permintaan pangan di tingkat rumah tangga tani diestimasi dengan menggunakan metode Ordinary Least Square (OLS), adapun hasil regresi dapat dilihat pada Tabel 1.

Uji ketepatan model berdasarkan nilai koefisien determinasi $\left(\mathrm{R}^{2}\right)$ sebesar 0,6395 menunjukkan bahwa sekitar $63,95 \%$ variasi permintaan pangan rumah tangga petani padi di Provinsi Riau mampu dijelaskan oleh variabel harga beras, harga ubi, harga telur, harga daging ayam, harga ikan, harga minyak goreng, usia kepala rumah tangga, tingkat pendidikan petani, jumlah anggota rumah tangga, pendapatan rumah tangga, dan modal sosial sedangkan sisanya sebesar 36,05\% dijelaskan oleh variabel lain di luar model. Nilai uji keseluruhan variabel tersebut (F-hitung) menunjukkan bahwa nilai F-hitung $(31,926)$ lebih besar dari F-tabel $(3,920)$ pada tingkat kesalahan $1 \%$. Hal ini menunjukkan bahwa variabel harga beras, harga ubi, harga telur, harga daging ayam, harga ikan, harga minyak goreng, usia kepala rumah tangga, tingkat pendidikan petani, jumlah anggota rumah tangga, pendapatan rumah tangga, dan modal sosial secara bersama-sama berpengaruh nyata terhadap permintaan pangan rumah tangga tani di Provinsi Riau pada tingkat kepercayaan 99\%.

Variabel yang diduga memengaruhi permintaan pangan rumah tangga tani yang berpengaruh signifikan dengan koefisien yang bernilai positif adalah usia kepala rumah tangga, tingkat pendidikan petani, jumlah anggota rumah tangga, pendapatan rumah tangga, dan modal sosial. Adapun variabel harga beras, harga ubi, harga telur, harga daging ayam, harga ikan, dan harga minyak goreng menghasilkan koefisien yang bernilai negatif terhadap permintaan pangan rumah tangga petani padi di Provinsi Riau.
Dari 11 variabel yang diduga memengaruhi permintaan pangan rumah tangga tani, diketahui variabel-variabel yang berpengaruh secara signifikan adalah harga beras, harga telur, harga harga minyak goreng, usia kepala rumah tangga, tingkat pendidikan petani, jumlah anggota rumah tangga, dan modal sosial. Adapun variabel-variabel harga ubi, harga daging ayam, harga ikan, dan pendapatan rumah tangga secara statistik tidak berpengaruh signifikan terhadap permintaan pangan rumah tangga petani padi di Provinsi Riau.

Dari Tabel 1, variabel harga beras berpengaruh nyata dan signifikan pada taraf kepercayaan $90 \%$ dan bernilai negatif. Ini menunjukkan jika harga beras naik sebesar $1 \%$ dengan asumsi variabel lain dalam model tetap maka permintaan pangan rumah tangga tani turun sebesar $0,1677 \%$. Hal ini juga sejalan dengan Wiwiek et al. (2007) bahwa harga beras signifikan berpengaruh negatif terhadap konsumsi beras dengan elastisitas $-0,0222$. Selanjutnya, variabel harga telur berpengaruh nyata dan negatif terhadap permintaan pangan rumah tangga tani pada tingkat kepercayaan 99\%, hal ini berarti jika harga telur di pasaran naik sebesar $1 \%$ dengan asumsi variabel lain dalam model tetap maka permintaan pangan rumah tangga tani akan menurun sebesar $0,0805 \%$. Selanjutnya, harga minyak goreng berpengaruh sangat nyata dan signifikan dengan nilai koefisien negatif pada tingkat kepercayaan $99 \%$. Hal ini menunjukkan bahwa jika harga minyak goreng di pasaran naik sebesar 1\% dengan asumsi variabel lain dalam model tetap maka permintaan pangan rumah tangga tani akan menurun sebesar $0,1677 \%$.

Variabel harga-harga bahan pangan akan memengaruhi akses pangan rumah tangga, dimana kenaikan hargaharga. Namun, tidak diimbangi dengan kenaikan pendapatan akan berakibat rendahnya daya beli. Irawan (2005) menjelaskan bahwa kebijakan subsidi harga input akan membantu untuk mewujudkan strategi cost untuk mendukung penyediaan lapangan kerja di sektor pertanian, diantaranya subsidi pupuk maupun BBM. Oleh karena itu, kebijakan pemerintah mengendalikan kenaikan harga bahan pokok dirasa sangat perlu demi kestabilan masyarakat.

Variabel karakteristik rumah tangga tani, yakni usia kepala rumah tangga berpengaruh nyata pada tingkat kepercayaan $90 \%$ dan bertanda positif. Hal ini menunjukkan bahwa jika usia kepala rumah tangga bertambah $1 \%$ dengan asumsi variabel lain dalam model tetap maka permintaan pangan rumah tangga tani naik 
0,2131\%. Kifli et al. (2015) menjelaskan faktor usia memberikan pengaruh positif pada probabilitas odd ratio rumah tangga tani untuk berstatus tahan pangan. Seiring peningkatan usia kemampuan tenaga, rasional, keahlian, dan kemampuan manajemen semakin meningkat sehingga berkorelasi positif pada ketahanan pangan rumah tangganya. Namun, pada suatu saat akan mencapai usia puncak dan akan mulai menurun kembali yang ditunjukkan dengan fungsi kuadratik. Perkiraan titik puncak (turning point) adalah pada umur 47-48 tahun.

Tingkat pendidikan petani berpengaruh nyata dan signifikan pada tingkat kepercayaan 95\% dengan tanda koefisien positif. Ini berarti jika tingkat pendidikan petani naik $1 \%$ dengan asumsi variabel lain dalam model tetap maka permintaan pangan rumah tangga tani naik $0,1459 \%$. Usia dan tingkat pendidikan kepala rumah tangga berkaitan erat terhadap pemilihan pola konsumsi pangan dan usaha meningkatkan ketahanan pangan rumah tangga. Kifli dan Saputri (2016) menunjukkan bahwa rumah tangga dengan pola konsumsi pangan terpenuhi $(75,61 \%)$ termasuk rumah tangga yang tahan pangan. Hasil bivariat ini memiliki nilai PR 3,7 dan terdapat hubungan yang bermakna. Interpretasi hasil tersebut adalah rumah tangga dari keluarga yang pola konsumsi pangannya tidak terpenuhi yang menyebabkan 3,7 kali lebih besar menjadi tidak tahan pangan. Faktor usia memberikan pengaruh positif pada probabilitas odd ratio rumah tangga tani untuk berstatus tahan pangan.

Demikian juga faktor pendidikan dan pengalaman sangat berpengaruh dalam peningkatan produksi pertanian, sebagaimana dikemukakan Pray and Nagarajan (2000) bahwa pendidikan dan pengalaman telah berkontribusi besar terhadap peningkatan produktivitas pertanian di India, dengan produksi pertanian meningkat pada tingkat tahunan sekitar 2,68\% per tahun dari tahun 1961 sampai 2007. Ristianingrum et al. (2016) menyatakan tingkat pendidikan petani yang rendah menyebabkan kurangnya pengetahuan dan kesadaran petani tentang kelestarian lingkungan, di sisi lain kurangnya pengetahuan dan keterampilan petani, belum adanya kebijakan dan kurangnya dukungan infrastruktur karena masih adanya kekhawatiran terjadinya penurunan produksi padi.

Hasil ini memiliki kesamaan dengan hasil penelitian Ruslan (2013) yang menunjukkan bahwa partisipasi keluarga dan pendidikan petani merupakan atribut sensitif terhadap keberlanjutan perkebunan inti rakyat kelapa sawit dan agribisnis sapi perah. Untuk itu maka diperlukan usaha-usaha untuk peningkatan kapasitas petani misalnya melalui pendidikan (formal ataupun non formal), misalnya melaui penyuluhan agar petani dapat mengadopsi teknologi termasuk manajerial skill agar mampu lebih produktif dan memiliki daya saing.

Variabel jumlah anggota rumah tangga berpengaruh sangat nyata terhadap permintaan pangan rumah tangga tani pada tingkat kepercayaan $99 \%$ dengan tanda positif. Hal ini menunjukkan bahwa jika jumlah anggota rumah tangga bertambah sebesar 1\% dengan asumsi variabel lain dalam model tetap maka permintaan pangan rumah tangga petani padi di Provinsi Riau akan meningkat $0,4227 \%$. Jumlah anggota keluarga secara langsung akan meningkatkan konsumsi dan permintaan pangan, semakin banyak anggota rumah tangga maka semakin besar pula kebutuhan pangan rumah tangga. Kifli et al. (2015) menyatakan bahwa jumlah anggota rumah tangga berpengaruh signifikan terhadap kesejahteraan rumah tangga namun dengan korelasi negatif. Hal ini cukup logis mengingat semakin banyak kebutuhan yang harus dipenuhi ketika suatu rumah tangga memiliki banyak anggota. Terlebih lagi ketika anggota rumah tangga tersebut merupakan tenaga kerja tidak produktif.

Lebih jauh lagi, variabel modal sosial (social capital) secara statistik menunjukkan pengaruh yang sangat signifikan terhadap permintaan pangan rumah tangga petani padi di Provinsi Riau. Pengaruh modal sosial sangat nyata terhadap permintaan pangan rumah tangga petani padi pada tingkat kepercayaan 99\% dengan tanda positif. Hal menunjukkan bahwa jika nilai-nilai modal sosial meningkat $1 \%$ dengan asumsi variabel lain dalam model tetap maka konsumsi dan permintaan pangan rumah tangga tani meningkat $1,3043 \%$. Hal ini mengindikasikan bahwa modal sosial masyarakat yang dibangun dari empat aspek, yakni kepercayaan, jaringan sosial dalam struktur dukungan, norma dan nilai, serta tingkat partisipasi dalam organisasi berkontribusi positif terhadap permintaan pangan rumah tangga petani padi di Provinsi Riau.

Modal sosial dari aspek kepercayaan yang diukur dari 10 konstruksi. Adapun konstruksi tersebut adalah hubungan baik dengan sesama masyarakat di lingkungan kampung, umumnya kebanyakan orang dapat dipercaya, selalu berpikir positif terhadap orang lain, rasa aman terhadap lingkungan kampung, baik 
bagi warga maupun orang dari luar kampung, orangorang di lingkungan dapat dipercaya, kunjungan ke rumah tetangga, suka memberikan pertolongan kepada sesama, kejadian seperti perkelahian, pencurian atau tindak kejahatan lainnya di lingkungan kampung, tingkat kepercayaan dalam partai politik, politisi, polisi dan pegawai negeri untuk bertindak demi publik yang baik, dan tingkat kepercayaan di lingkungan gerejagereja/masjid.

Modal sosial yang diukur dari aspek jaringan sosial dan struktur dukungan juga diukur dari 10 konstruksi. Adapun konstruksi tersebut adalah frekuensi kontak dengan keluarga dan teman (di luar rumah tangga), jika ada orang lain/warga sakit biasa dijenguk, kunjungan ke rumah tetangga, suka memberi pertolongan, meskipun tidak kenal dengan orang yang meminta pertolongan, tetangga juga biasa berkunjung di rumah, ikut membantu jika ada yang berduka, mengikuti perkembangan informasi melalui media masa, pengaruh suku lain terhadap kehidupan masyarakat di kampung, kenalan di luar lingkungan kampung, dan dapat berhubungan/ berkomunikasi dengan mereka walaupun jauh dari rumah.

Modal sosial dari aspek norma dan nilai yang disusun dari 10 konstruksi. Adapun konstruksi tersebut adalah keinginan untuk dihargai, selalu menghargai hasil karya orang lain, bila disakiti orang lain maka saya harus membalasnya, suatu saat tertentu pasti membutuhkan pertolongan orang lain, suatu saat tertentu orang lain pasti membutuhkan pertolongan, setiap orang pasti akan menuai hasil dari semua perbuatannya, keberadaannya sangat diharapkan dalam kelompok, pertolongan yang diberikan, berarti mendapat kepercayaan dari kelompok, kerja sama dalam membuka kebun, dan makan bersama dalam suatu pesta adat penting untuk kebersamaan.

Modal sosial dari aspek tingkat partisipasi dalam organisasi yang diukur dari enam konstruksi. Adapun konstruksi tersebut adalah partisipasi dalam iuran/ sumbangan untuk organisasi, kehadiran dalam rapatrapat organisasi, partisipasi menyampaikan pendapat dalam rapat, keterlibatan dalam pengambilan keputusan di organisasi, keaktifan dalam kegiatan-kegiatan organisasi, dan kebebasan mengemukakan pendapat/ berbicara dalam rapat juga memberikan kontribusi positif terhadap tingkat ketahanan pangan rumah tangga tani. Hasil penelitian Innocent dan Adefila (2014) menyimpulkan pentingnya pelatihan (training) dan pelatihan kembali (re-training) bagi para anggota untuk memiliki keterampilan dan pengetahuan yang diperlukan bagi organisasi agar berfungsi dengan baik. Hal ini dapat dicapai melalui pelaksanaan seminar, workshop, atau kegiatan lain. Selanjutnya, Ruslan (2013) juga menunjukkan bahwa lembaga keuangan merupakan atribut yang sensitif terhadap keberlanjutan perkebunan inti rakyat kelapa sawit.

Banyak studi telah menunjukkan bahwa umumnya rumah tangga perdesaan kekurangan akses terhadap lembaga kuangan baik formal maupun informal. Adanya keterbatasan modal petani maka dukungan permodalan dari lembaga keuangan merupakan atribut yang penting (Ristianingrum et al. 2016). Hal yang sama juga dijelaskan Nuryantono (2007) bahwa sebagian besar rumah tangga dibatasi kredit karena kurangnya jaminan dan masalah seleksi diri, studi kasus di daerah perdesaan Sulawesi tengah menunjukkan hanya $21,5 \%$ ruamah tangga memiliki akses ke kredit formal dan hanya $18,1 \%$ rumah tangga tersebut yang tidak dibatasi kredit. Menurut Akhmadi et al. (2016) berdasarkan hasil perhitungan Total Attractiveness Scores (TAS) menunjukkan bahwa strategi penguatan sumberdaya manusia dan kelembagaan Gapoktan melalui program pendidikan khusus pengembangan manajemen agribisnis bagi petani adalah strategi yang terbaik. Di sisi lain, Saputra et al. (2009) menyebutkan bahwa peningkatan sumber daya manusia bagi peternak bisa dilakukan dengan memberikan pelatihan dan pembinaan seperti mengelola kelompok, koperasi, pengembangan permodalan, manajemen usaha, distribusi dan pemasaran.

Penguatan permodalan, kapasitas SDM (keterampilan teknis dan kapabilitas manajerialnya), penguatan kelembagaan petani (manajemen/kepengurusan, peningkatan partisipasi anggota, permodalan kelompok, serta peningkatan adopsi teknologi) pada rumah tangga tani mutlak untuk dilakukan mengingat pada umumnya petani mengalami keterbatasan. Keseluruhan konstruksi penyusun modal sosial di masyarakat tersebut perlu terus didorong dan dikembangkan dalam interaksi sosial di masyarakat karena memberikan pengaruh yang positif dan signifikan terhadap peningkatan konsumsi dan permintaan pangan rumah tangga petani padi di Provinsi Riau. 


\section{Implikasi Manajerial}

Pemerintah Provinsi Riau hendaknya meningkatkan kinerja dinas dan instansi terkait agar lebih berperan terhadap peningkatan kemampuan dan kapasitas petani agar mampu lebih produktif dalam produksi termasuk kemampuan manajerial dan skill. Upaya peningkatan skill petani diantaranya melalui pendampingan petani, penyuluhan dan komunikasi pertanian diperlukan agar petani lebih terampil dan dapat mengadopsi teknologi terkini guna menunjang produksi dan produktivitas pertanian serta keterampilan teknis lainnya yang mendukung. Upaya peningkatan kemampuan manajerial dapat dilakukan di sisi lain sosialisasi dan pemahaman terhadap pola konsumsi, gizi dan upaya peningkatan ketahanan pangan keluarga untuk kualitas hidup yang lebih baik.

Pemerintah Provinsi Riau perlu melakukan perencanaan integratif di sektor pertanian serta membangun kerja sama antar sektor dan lintas bidang dalam memajukan sektor pertanian dan mensejahterakan petani agar memiliki daya saing. Petani harus mampu berproduksi dan bertani secara efektif dan efisien sehingga peningkatan produksi terus tumbuh dan mampu menyediakan kebutuhan baik pangan maupun nonpangan, di sisi lain menciptakan lapangan kerja dan menyerap tenaga kerja secara lebih banyak dan ditopang pula dengan partisipasi aktif masyarakat terhadap pembangunan dalam peningkatan kesejahteraan dengan bekal modal sosial yang berkembang di masyarakat.

\section{KESIMPULAN DAN SARAN}

\section{Kesimpulan}

Hasil penelitian dapat disimpulkan bahwa variabel usia kepala rumah tangga, tingkat pendidikan petani, jumlah anggota rumah tangga, pendapatan rumah tangga, dan modal sosial berpengaruh secara positif terhadap permintaan pangan rumah tangga tani sedangkan variabel harga beras, harga ubi, harga telur, harga daging ayam, harga ikan, dan harga minyak goreng berpengaruh secara negatif terhadap peningkatan permintaan pangan rumah tangga tani.

Modal sosial (social capital) dalam masyarakat yang dibangun dari empat aspek, yakni kepercayaan, jaringan sosial dalam struktur dukungan, nilai dan norma, dan tingkat partisipasi dalam organisasi memberikan pengaruh signifikan dan berkontribusi positif terhadap peningkatan permintaan pangan rumah tangga tani.

\section{Saran}

Dalam rangka meningkatkan diversifikasi konsumsi pangan perlu terus ditingkatkan dan didukung program peningkatan diversifikasi pangan oleh pemerintah daerah. Diversifikasi tersebut dapat berupa pangan alternatif selain beras sebagai pengganti karbohidrat, dan juga meningkatakan diversifikasi pangan kepada protein selain karbohidrat. Untuk itu sangat penting bagi pemerintah daerah dan instansi terkait lainnya terus mengupayakan peningkatan konsumsi dan diversifikasi pangan rumah tangga sesuai dengan modal sosial masyarakat.

Daerah harus bangga dengan kearifan lokal yang dimiliki sehingga ini menjadikannya unik dari daerah lain. Untuk itu sangat penting menanamkan kesadaran kepada seluruh penduduknya untuk menghormati dan menghargai kearifan lokal tersebut. Kearifan lokal yang terbangun di masyarakat seperti nilai-nilai kebersamaan, antar mengantar makanan merupakan bentuk dukungan sosial kepada sekitarnya sehingga tetangganya tidak sampai kesulitan memperoleh bahan pangan.

\section{UCAPAN TERIMA KASIH}

Terima kasih dan Penghargaan yang tinggi kepada Kementerian Riset, Teknologi dan Perguruan Tinggi atas pembiayaan penelitian melalui Hibah Penelitian Unggulan Perguruan Tinggi (PUPT) Baru, Nomor: LPPM-UGM/1392/LIT/2013 dan Hibah Penelitian Unggulan Perguruan Tinggi (PUPT) Lanjutan Nomor: LPPM-UGM/ 441/ LIT/ 2014.

\section{DAFTAR PUSTAKA}

Akhmadi, SiregarH,HutagaolMP.2016. Pengembangan agribisnis sebagai strategi penanggulangan kemiskinan di perdesaan. Jurnal Manajemen dan Agribisnis 13(3): 240-253. doi:http://dx.doi. org/10.17358/jma.13.3.240

Burt RS. 1992. Excerpt from The Sosial Structure of Competition, in Structure Holes: The Social Structure of Competition. Cambridge, MA and London: Harvard University. In Elinor 
Ostrom and T.K. Ahn. 2003. Foundation of Social Capital. Massachusetts: Edward Elgar Publishing Limited.

Chalamwong Y. 1985. Rural Labour Supply in Thailand; a recent experience. In R.T Shand (ed) Off-farm Employment in the Development of Rural Asia, Australian Nat University I : 257-271.

Cohen S, Prusak L. 2001. In Good Company: How Social Capital Makes Organization Work. London: Harvard Business Pres.

Coleman J. 1999. Social Capital in the Creation of Human Capital. Cambridge Mass: Harvard University Press.

Cox E. 1995. A Truly Civil Society. Sydney: ABC Boook.

Fukuyama F. 1995. Social capital and the global economy. Foreign Affairs 74(5): 89-103.

Greene WH. 1993. Econometric Analysis. New York: Macmillan Publishing Company.

Gudjarati DN. 2003. Basic Econometrics, Forth Ed. Boston: Mc Graw Hill.

Hasbullah J. 2006. Sosial Kapital: Menuju Keunggulan Budaya Manusia Indonesia. Jakarta: MR-United Press.

Innocent Y, Adefila JO. 2014. Farmers' cooperatives and agricultural development in kwali area council federal capital territory Abuja, Nigeria. International Journal of Humanities and Social Science 4(7.1): 161-169.

Irawan A. 2005. Analisis Perilaku Sektor Pertanian di Indonesia: Aplikasi Vector Error Correction Model. Jurnal Manajemen dan Agribisnis 2(1): 53-72.

Kawachi I, Kennedy B, Lochner K, Prothrow-Stith D. 1997. Social capital, income inequality, and mortality. American Journal of Public Health, 87:1491-1498.

Kifli FW, Saputri R. 2016. Pola Konsumsi Pangan Terhadap Ketahanan Dan Kerentanan Rumah Tangga Tani di Propinsi Riau. Di dalam: Prosiding Seminar Nasional dan Gelar Produk Penelitian dan PPM dengan tema "Meneguhkan Peran Penelitian dan Pengabdian kepada Masyarakat dalam Memuliakan Martabat Manusia" di LPPM UNY. Yogyakarta.

Kifli FW, Mulyo JH, Sugiyarto, Utami AW. 2015. Kaitan Perubahan Iklim, Ketahanan Pangan Dan Kesejahteraan Rumah Tangga di Propinsi Riau. Di Dalam: Prosiding Seminar Nasional dan Gelar Produk Penelitian dan PPM dengan tema "Penelitian dan PPM untuk Mewujudkan Insan
Unggul" di LPPM UNY. Yogyakarta.

Lochner K, Kawachi I, Kennedy B. 1999. Social capital: A guide to its measurement. Health \& Place 5(4): 259-270.

Masyhuri. 2001. Pembangunan Pertanian Masa Depan. Dalam: Pembangunan Pertanian di Era Otonomi Daerah (Edisi Revisi). Yogyakarta: LP2KP Pustaka Karya.

Nakajima C. 2004. Subsistance and Comercial Family Farms: theoritical Models of Subjective Equilibrium, dalam Wharton $J$, $C$. $R$ (ed): Subsistence Agriculture and Economic Development. Chicago:Aldine P.C.

Nuryantono N.2007.Creditrationing of farm households and agricultural production: empirical evidence in rural areas of Central Sulawesi, Indonesia. Jurnal Manajemen dan Agribisnis 4(1): 15-21.

Partha D, Ismail S. 1999. Social Capital A Multifaceted Perspective. Washington DC: The World Bank.

Pray CE, Nagarajan L. 2012. Innovation and research by private agribusiness in india. International Food Policy Research Institute. https://www. ifpri.org/publication/innovation-and-researchprivate-agribusiness-india. [12 Juni 2016].

Pyndick RS, Rubinfield DL. 1998a. Econometric Models and Aconomic Forecasts. 4th Edition. New Jersey: Irwin and McGraw Hill.

Pyndick RS, Rubinfield DL. 1998b. Microeconomics. 4th edition. New Jersey: Prentice-Hall Inc.

Rose R. 2000. How much does social capital add to individual health? A survey study of Russians. Social Science \& Medicine 51:1421-1435.

Ristianingrum A, Chozin MA, Machfud, Sugiyanta, Mulatsih S. 2016. Optimalisasi keberlanjutan pengembangan usaha padi organik di Kabupaten Cianjur, Jawabarat. Jurnal Manajemen dan Agribisnis 13(1): 37.

Runyan D, Hunter W, Socolar R, Amaya-Jackson L, English D, Landsverk J, Dubowitz H, Browne D, Bangdiwala S, Mathew R. 1998. Children who prosper in unfavorable environments: The relationship to social capital. Pediatrics 101:1218.

Ruslan. 2013. Model pengelolaan perkebunan inti rakyat kelapa sawit berkelanjutan. Ekologia 13(1):33-44.

Sadoulet E, Janvry A. 1995. Quantitative Development Policy Analisys. Baltimore: The John Hopkins University Press.

Saputra H, Daryanto A, Hendrawan DS. 2009. Strategi pengembangan ternak sapi potong berwawasan 
agribisnis di Provinsi Aceh. Jurnal Manajemen dan Agribisnis 6(2): 152-162.

Singh I, Lin S, John S. 1986. Agricultural Household Models. Extensions, Applications, and Policy. The Johns Hopkins University Press.

Solow RM. 1999. Notes Social Capital and Economic Performance. In Partha D, Ismail S. 1999. Social Capital A Multifaceted Perspective. Washington DC: The World Bank.
Wiryamarta F, Mulyo JH. 2009. Kinerja Sektor Pertanian di Propinsi Riau pada Era Otonomi Daerah. Yogyakarta: Fakultas Pertanian Gadjah Mada.

Wiwiek R, Hutagaol MP, Siregar H. 2007. Dampak desentralisasi fiskal terhadap kinerja fiskal daerah dan ketahanan pangan di wilayah Provinsi Jawa Barat. Jurnal Manajemen dan Agribisnis 4(2): 103-117. 